\title{
Spatial regional infrastructural systems sustainable development: priorities and measures
}

\author{
Elena Shishkina, and Nadezhda Surnina \\ Ural State University of Economics, st. March 8 / NarodnayaVolya, 62/45, 620144 Yekaterinburg, \\ Russia
}

\begin{abstract}
The article dwells on formation features of the priorities and parameters for assessing the sustainable development of spatial infrastructure systems in the region. The priorities of the stability of spatial infrastructural systems have been established - the ability of stable functioning in conditions of external influences, adaptability to them. The strategic development goals correspondence study of spatial infrastructure systems to the goals and objectives of sustainable development was carried out. The absence of consistency and complexity in the formation of the foundations of sustainable development in strategies, programs and projects for the development of spatial infrastructure systems of the Russian Federation was revealed. The indicators of sustainable development reflecting various strategic planning of spatial infrastructure systems were analyzed. It has been determined that the parameters for achieving the Sustainable Development Goals in the context of the constituent entities of the Russian Federation are currently not being developed, and indicators of the availability and availability of infrastructure are used as target parameters, which can reflect the degree of satisfaction need for it to solve the problems of socio-economic development of the territories.
\end{abstract}

\section{Introduction}

At present sustainable development goal achievement is spreading over as a strategic and universal approach to the countries and regions general development. Sustainable development goal is firmly integrated into the Russian Federation national and regional policy which makes it possible to establish and qualitatively measure. The Agenda adopted September, 252015 in the field of sustainable development up to the 2030 period takes into account tasks and goals of the issue that bear complex structure and are closely connected with infrastructure development. It is topical to assess the criteria and methods of realization the stability of infrastructural systems that allow to work out proper program documents.

The aim of the article is to investigate sustainable development priorities of the regional spatial infrastructure systems, to assess their implementation possibilities as well the possibilities in the aspect of statistics. 
The study objects are electric and transport spatial infrastructure regional systems that are physically and economically related.

\section{Regional spatial infrastructure systems sustainable development theoretical foundations study}

The concept of sustainable development has been extensively analyzed in the scientific literature. The issues of sustainable development and their systems are studied in the works of N. Timchuk, L.L. Terekhova, L.I. Abalkina, V.N. Leksina, SilinaYa.P., A.N. Shvetsova and others $[1,2,3,4,5,6,7,8]$ in which the general properties of the stability of the regional system are the reliability of the economic structure, the adaptability and elasticity of regional reproduction, the ability to function in conditions close to equilibrium, to constant renewal and improvement. D.V. Presnyakova [9] proposes to distinguish between the concepts of sustainable growth and development on the basis of qualitative and quantitative parameters of the regional economic system sustainability. Thus, the main characteristics of stability for territories, their spatial systems are the ability of the system to function stably under external influences, adaptability to them.

In the modern period, the category of "sustainable development" has received formalization within the framework of the 2030 Agenda for Sustainable Development (UN General Assembly, 2015) [10]. The Sustainable Development Goals and their associated targets are interlinked, allowing them to be seen as part of a single system, so efforts to achieve the SDGs must be comprehensive. Generally, scientists identify about 300 interrelationships between the goals of sustainable development [11]. Let us consider in details the relationship between sustainable development goals and spatial infrastructure systems of the region - energy and transport: low-cost and clean energy, industrialization, innovation and infrastructure, sustainable cities and settlements, which allow us to trace the consistency of goals for the regional development.

1. Inexpensive and clean energy. The indicators of accessibility to energy sources and energy efficiency are set as the most important indicator. The energy infrastructure is considered to be a major factor the territories sustainable development, influences the location of economic facilities, the distribution of the population, this is how its supporting function is being manifested [12].

2. Industrialization, innovation and infrastructure. Investments in infrastructure transport, energy supply, information and communication technologies - are necessary to achieve sustainable development, and also are a condition for ensuring growth in labor productivity, income, and improving the results of the provision of various services.

3. Sustainable cities and towns. The active development of cities increases the load on infrastructure systems and makes it necessary to increase the reliability of basic infrastructures in terms of energy supply, transport, and the social sphere. The development of infrastructural systems is an important factor in ensuring the sustainable development of territories.

Thus, the dual meaning of spatial infrastructural systems is manifested as a necessary condition for the implementation of the sustainable development principles, as well as the need for sustainability and stability of the infrastructure itself.

\section{Regional spatial infrastructure systems sustainable development priorities and parameters}

Currently, most of the tasks of sustainable development, incl. spatial infrastructural systems of the region are implemented through strategies, programs of socio-economic development 
of the Russian Federation and the constituent entities of the Russian Federation, departmental programs and projects. At the same time, there are no documents at the national and regional levels aimed exclusively at the implementation of the UN SDGs, and a sustainable development strategy has not been formulated. Despite the availability of works devoted to certain aspects of the implementation of the SDGs $[13 ; 14 ; 15 ; 16]$, no work has been done to compare the goals and priorities of programs for the development of spatial infrastructure systems with the SDG targets. Let us analyze the compliance of the goals of strategic development of spatial infrastructure systems with the goals of sustainable development based on the method of comparative analysis of national, regional, departmental documents, and their content analysis. The results of the analysis are systematized in Table 1. It should be noted that the authors have not assessed the effectiveness of the implemented or planned measures in the field of sustainable development.

Table 1. Analysis of the spatial infrastructure systems strategic development goals compliance with the sustainable development goals and objectives

\begin{tabular}{|c|c|c|c|}
\hline $\begin{array}{l}\text { Sustainable } \\
\text { developmen } \\
\text { t objectives }\end{array}$ & $\begin{array}{c}\text { UN Sustainable } \\
\text { Development } \\
\text { Challenges }\end{array}$ & $\begin{array}{c}\text { Reflection of the } \\
\text { objectives of the UN } \\
\text { SDGs in the provisions } \\
\text { of the existing strategic } \\
\text { documents }\end{array}$ & Document Title \\
\hline $\begin{array}{c}7 . \\
\text { Inexpensive } \\
\text { and clean } \\
\text { energy }\end{array}$ & $\begin{array}{l}\text { 7.1 Universal access } \\
\text { to affordable, } \\
\text { reliable and modern } \\
\text { energy supply) } \\
\text { 7.2 Renewable } \\
\text { energies, } 7.3 \text { Energy } \\
\text { efficiency } \\
\text { improvements } 7 . b \\
\text { Infrastructure } \\
\text { expansion and } \\
\text { technology upgrades } \\
\text { for a modern and } \\
\text { sustainable energy } \\
\text { supply }\end{array}$ & $\begin{array}{l}\text { development of electricity } \\
\text { infrastructure, guaranteed } \\
\text { provision of affordable } \\
\text { electricity; sustainable } \\
\text { energy supply to } \\
\text { consumers; development } \\
\text { of centralized energy } \\
\text { systems; development of } \\
\text { distributed generation; } \\
\text { introduction of intelligent } \\
\text { control systems for power } \\
\text { grid facilities based on } \\
\text { digital technologies }\end{array}$ & $\begin{array}{l}\text { Strategy for the } \\
\text { development of the } \\
\text { power grid complex of } \\
\text { the Russian Federation } \\
\text { until } 2030 \text { (approved on } \\
\text { April 3, 2013, No. 511- } \\
\text { r); Energy Strategy of } \\
\text { the Russian Federation } \\
\text { for the period up to } 2035 \\
\text { (approved by the Order } \\
\text { of the Government of } \\
\text { the Russian Federation } \\
\text { dated 09.06.2020 No. } \\
\text { 1523-r); Scheme and } \\
\text { program for the } \\
\text { development of the } \\
\text { Unified Energy System } \\
\text { of the Russian } \\
\text { Federation for } 2019 \text { - } \\
2025 \text { (approved by order } \\
\text { of the Ministry of } \\
\text { Energy of Russia dated } \\
\text { February } 28,2019 \mathrm{~N} \\
174 \text { )) }\end{array}$ \\
\hline
\end{tabular}


Table 1. Continued

\begin{tabular}{|c|c|c|c|}
\hline $\begin{array}{c}9 . \\
\text { Industrializat } \\
\text { ion, } \\
\text { innovation } \\
\text { and } \\
\text { infrastructur } \\
\text { e }\end{array}$ & $\begin{array}{l}\text { 9.1 Development of } \\
\text { a quality, reliable, } \\
\text { sustainable and } \\
\text { resilient } \\
\text { infrastructure } \\
\text { 9.2 Sustainable } \\
\text { industrialization } \\
\text { 9.4 Modernization of } \\
\text { infrastructure and re- } \\
\text { equipment of } \\
\text { industrial enterprises }\end{array}$ & $\begin{array}{l}\text { modernization and } \\
\text { expansion of the entire } \\
\text { main infrastructure of the } \\
\text { country; doubling the cost } \\
\text { of spatial development; } \\
\text { renovation of regional and } \\
\text { local roads; increasing the } \\
\text { throughput capacity of } \\
\text { BAM and Transsib to } 180 \\
\text { million tons by } 2024 \text {; } \\
\text { development of digital and } \\
\text { innovative infrastructure }\end{array}$ & $\begin{array}{l}\text { Comprehensive } \\
\text { modernization and } \\
\text { expansion plan } \\
\text { backbone infrastructure } \\
\text { (approved September } 30 \\
2018 \text { No. 2101-r); } \\
\text { Digital Transport and } \\
\text { Logistics CTL } \\
\text { (departmental project); } \\
\text { Concept digital } \\
\text { transformation 2030. } \\
\text { PJSC "Rosseti" }\end{array}$ \\
\hline $\begin{array}{c}11 . \\
\text { Sustainable } \\
\text { cities and } \\
\text { towns }\end{array}$ & $\begin{array}{l}\text { 11.2 Safe, } \\
\text { affordable, } \\
\text { affordable and } \\
\text { environmentally } \\
\text { sustainable transport } \\
\text { systems } \\
\text { 11.a Improving the } \\
\text { quality of national } \\
\text { and regional } \\
\text { development } \\
\text { planning }\end{array}$ & $\begin{array}{l}\text { improving the quality of } \\
\text { urban infrastructure; } \\
\text { creation of a mechanism } \\
\text { for the direct participation } \\
\text { of citizens in the } \\
\text { formation of a comfortable } \\
\text { urban environment, } \\
\text { ensuring the availability } \\
\text { and reliability of power } \\
\text { supply }\end{array}$ & $\begin{array}{l}\text { The strategy of spatial } \\
\text { development of the } \\
\text { Russian Federation until } \\
2025 \text { (approved on } \\
\text { February 13, 2019, No. } \\
\text { 207-r); Digital transport } \\
\text { and logistics CTL } \\
\text { (departmental project) } \\
\text { Departmental project } \\
\text { "Digital Energy" }\end{array}$ \\
\hline
\end{tabular}

Note: Compiled from the Voluntary National Review of the Implementation of the 2030 Agenda for Sustainable Development. M., 2020.240 p.

The study of the correspondence of the strategic development priorities of spatial infrastructure systems to the goals and objectives of sustainable development shows that the SDGs are fully integrated into the strategies, programs and projects for the development of spatial infrastructure systems of the Russian Federation for the medium and long term; strategic tasks of sustainable development of spatial infrastructure systems of the region are formed at various hierarchical levels - international, national, regional and require taking into account the interests of many subjects on the basis of the formation of a complex of interrelated documents and information platforms; the ecological aspect of the development of spatial infrastructural systems of the region is implemented within the framework of separate documents on ecology, not strategic development, which shows the lack of consistency and complexity in the formation of the foundations of sustainable development. An analysis of the formation of official data of the Federal State Statistics Service of the Russian Federation, as well as departmental, corporate strategic documents shows that indicators of the availability and availability of infrastructure are used as target parameters of the sustainability of spatial infrastructure systems, which can reflect the degree of satisfaction of the need for them to solve the problems of socio-economic development territories.

The draft list of national SDG indicators was developed in accordance with the UN General Assembly resolution A / RES / 71/313 of July 6, 2017 on the development of national sets of SDG indicators, taking into account national priorities, local conditions and 
statistical capacity. It reflects national characteristics and takes into account the tasks defined in the Decree of the President of the Russian Federation of May 7, 2018 No. 204 "On national goals and strategic objectives of the development of the Russian Federation for the period up to 2024", strategic documents of the Government of the Russian Federation, as well as national and federal projects. The sources of information for the formation of a system of indicators for achieving the SDGs are data from Rosstat, the Ministry of Internal Affairs of Russia, the Ministry of Natural Resources of Russia, the Ministry of Agriculture of the Russian Federation, the Ministry of Finance of the Russian Federation, the Ministry of Emergencies of Russia, the Treasury of Russia, Rosvodresursy, Roshydromet, Rosleskhoz, etc.

The study of the parameters for achieving sustainable development goals shows that in the areas under consideration (SDGs No. 7, 9, 11), only half $(50 \%)$ of the possible indicators are being developed that have no direct connection with the development of infrastructure systems (Table 2).

Table 2. A sample of sustainable development indicators reflecting various spatial infrastructure systems strategic planning

\begin{tabular}{|c|c|c|c|c|c|}
\hline $\begin{array}{c}\text { Indicator name in accordance with } \\
\text { SDGs }\end{array}$ & 2015 & 2016 & 2017 & 2018 & $\begin{array}{l}\text { Growthrate } \\
(2018 / 2015), \%\end{array}$ \\
\hline $\begin{array}{l}\text { Share of population with access to } \\
\text { electricity (7.1.1), } \%\end{array}$ & - & 99,9 & - & 100 & $\begin{array}{c}100,1 \\
(* 2018 / 2016) \\
\end{array}$ \\
\hline $\begin{array}{l}\text { Share of renewable energy sources in total } \\
\text { final energy consumption }(7.2 .1), \%\end{array}$ & - & 0,21 & 0,21 & - & $\begin{array}{c}100,0 \\
(* 2017 / 2016 \\
\text { гг.) } \\
\end{array}$ \\
\hline $\begin{array}{l}\text { Energy intensity of gross domestic } \\
\text { product (GDP) for the year preceding the } \\
\text { previous one (7.3.1), kg of conventional } \\
\text { fuel per } 10 \text { thousand rubles, in current } \\
\text { prices }\end{array}$ & 106,8 & 104,9 & 99,9 & - & $\begin{array}{c}93,5 \\
(2017 / 2014 \\
\text { гг.) }\end{array}$ \\
\hline $\begin{array}{l}\text { The share of energy resources produced } \\
\text { using renewable energy sources in the } \\
\text { total volume of energy resources } \\
\text { production, } \%\end{array}$ & 15,8 & 17,0 & 17,0 & 17,3 & 109,1 \\
\hline $\begin{array}{l}\text { Value added of the "Manufacturing" } \\
\text { industry per capita for the year preceding } \\
\text { the previous one }(9.2 .1), \%\end{array}$ & 70818,3 & 70434,1 & 76630,4 & 87063,4 & 122,9 \\
\hline $\begin{array}{l}\text { Expenditures on research and } \\
\text { development and development work as a } \\
\text { percentage of the gross domestic product } \\
\text { of the Russian Federation }(9.5 .1), \%\end{array}$ & 1,10 & 1,10 & 1,11 & 1,0 & 90,9 \\
\hline $\begin{array}{l}\text { Number of researchers (in full-time } \\
\text { equivalent) per million inhabitants (9.5.2), } \\
\text { people }\end{array}$ & 3065,1 & 2921,5 & 2795,6 & 2764,5 & $90,2 \%$ \\
\hline $\begin{array}{l}\text { Cumulative official international support } \\
\text { (official development assistance and other } \\
\text { flows of official financing) directed to } \\
\text { infrastructure (9.a.1), USD million }\end{array}$ & - & - & 111,12 & 128,01 & $\begin{array}{c}115,2(* 2018 / \\
2017 \text { г.) }\end{array}$ \\
\hline $\begin{array}{l}\text { Density of public roads with hard surface } \\
\text { per } 1000 \text { sq. km of territory, km per } 1000 \\
\text { sq. km of territory }\end{array}$ & 61 & 62 & 62 & 63 & $103,3 \%$ \\
\hline $\begin{array}{l}\text { The ratio of the rate of commissioning of } \\
\text { residential buildings to the rate of } \\
\text { population growth (11.3.1) }\end{array}$ & 1,01 & 0,94 & 0,99 & 0,96 & $95,0 \%$ \\
\hline
\end{tabular}

Note: Calculated against the Sustainable Development Goal for the Russian Federation. 2019: Brief statistics collection / Rosstat - M., 2019 -39 p. 
Analysis of sustainable development indicators reflecting various strategic planning of spatial infrastructure systems for the 2015-2018 period. (since the adoption of the 2030 Agenda for Sustainable Development) [10], shows a positive trend in relation to SDG No. 7, while relative to SDG No. 9 and 11, growth rates are negative. The most significant changes are noted in terms of a decrease in the energy intensity of the gross domestic product by $6.5 \%$ over the period, as well as an increase in the share of energy resources produced using renewable energy sources by $9.1 \%$. The analysis shows that the official information on the indicators of achieving the Sustainable Development Goals in the context of the constituent entities of the Russian Federation is currently not being formed. The system of indicators of sustainable development of spatial infrastructure systems of the region is formed by a set of organizations of various hierarchical standards, the information base is represented by relative indicators and the magnitude of dynamics.

\section{Conclusions}

1. It has been determined that the main priorities of sustainability for spatial infrastructure systems are the ability to function stably under external influences and adaptability to them.

2. Analysis of compliance with the SDGs related to the development of spatial infrastructure systems of the region are the following- energy and transport: affordable and clean energy, industrialization, innovation and infrastructure, sustainable cities and settlements, which made it possible to establish the role of infrastructure systems for the implementation of the principles of sustainable development, as well as the need sustainability of infrastructure to achieve the SDGs.

3. It has been established that at present, the Russian Federation has not developed documents aimed exclusively at the implementation of the SDGs defined by the UN General Assembly in 2015, long-term period of various levels, which requires taking into account the interests of many subjects on the basis of the formation of a complex of interrelated documents and information platforms.

4. Analysis of indicators for sustainable development goals shows that most of the indicators defined as indicators of sustainable development are currently not being developed, and the indicators being developed are not directly related to the development of infrastructure systems. The SDG indicators formed within the framework of the national set of indicators for the subjects of the Russian Federation are currently absent.

5. Individual indicators formation analysis of the spatial infrastructure systems development on the basis of data from the official Federal State Statistics Service of the Russian Federation, departmental, corporate strategic documents led to the conclusion that availability indicators and infrastructure availability are used as target parameters, which can reflect the degree of satisfaction of the need for it for solving tasks of socio-economic development of territories.

\section{References}

1. P.M. Ivanov, Economics and mathematical methods, 42 (2), 52 (2006)

2. Y. Silin, IOP Conference Series: Earth and Environmental Science, 177 (1) (2018)

3. N.F. Timchuk, City and region: regulation of complex development, 19, (2004)

4. A.I. Borodin, N.N. Kiseleva, Bulletin of the Udmurt University, Economics and Law, 4 (2011) 
5. L.I. Abalkin, Problems of Economics, 12, 4 (1994)

6. V.N. Leksin, State and regions, Theory and practice of state regulation of territorial development (1997)

7. E.B. Dvoryadkina, C.I. Kaibicheva, I.Iэ Shurova, International Journal of Applied Business and Economic Research, 15, 43 (2017)

8. T.V. Uskova, E.N. Koposova, Problems of territory development, 43 (2008)

9. D.V. PresnyakovaSocio-economic phenomena and processes, 8 (2011)

10. Transforming Our World: The 2030 Agenda for Sustainable Development Resolution, https://www.un.org/

11. LM. Kuznetsov, A.A. Yankovskaya, Implementation of sustainable development goals: European and Russian experience collection of scientific articles based on the conference materials, 57 (2019)

12. N.M. Surnina, E.A. Shishkina, N.V. Novikova, A.G. Dyachkov, Mechanisms of infrastructural energy supply of regional development: monograph (2019)

13. S.N. Bobylev, L.M. Grigoriev, The UN Sustainable Development Goals and Russia: a report on human development in the Russian Federation (2016)

14. O.I. Dunaev, V.A. Nagornov, Public-private partnership, 2 (2017)

15. A.G. Sakharov, O.I. Kolmar, Bulletin of international organizations, 14 (1), 189 (2019)

16. L.G. Sudas, Public Administration. Electronic bulletin, 64 (2017) 